\title{
Effectiveness of Learning Using Online Discussion Methods Pandemic Period
}

\author{
Siti Halimah ${ }^{1 *}$, Norhayatun ${ }^{1,}$ Norlela $^{1}$, Ifan Julianta ${ }^{1}$, M.Hadianur ${ }^{1}$, Alivermana \\ Wiguna $^{2}$, Nugroho Kuncoro Yudho ${ }^{2}$
}

${ }^{I}$ Education Economic Departement, STKIP Muhammdiyah Sampit, Central Borneo Indonesia

${ }^{2}$ Guidance and Counseling Departement, STKIP Muhammdiyah Sampit, Central Borneo Indonesia

"Corresponding author.Email: siti_halimah@stkipmsampit.ac.id

\begin{abstract}
This research was conducted to find out the effectiveness of learning using online discussion methods pandemic period. The hypothesis proposed in this research is how the effectiveness of learning using online discussion methods pandemic period. Researcher used quantitative descriptive as research method. In collecting the data, researcher used a questionnaire with a nominal scale: Yes / no in total of 17 questionnaire items that have met the validity and reliability tests. The subjects of this research are students who took Introduction of management Subject totaled 14 respondents. Data analysis techniques in this research used categorization. To categorize the measurement results, they were grouped into three (3) categories, namely low, medium, high. The result shows that the effectiveness of learning using online discussion methods in learning in the category of pandemic is quite effective.
\end{abstract}

Keywords: Learning, Online Discussion Methods

\section{INTRODUCTION}

Covid-19 is an infectious disease caused by corona virus acute respiratory syndromes 2 . It was found to be widely spread to result in a global pandemic that continues to this day. Global pandemics also occur in Indonesia which has an impact on all fields of life. One of the effects of the covid-19 pandemic is education throughout the world, which is leading to the widespread closure of schools, Islamic School, universities and Islamic boarding schools. UNESCO (United Nations Educational, Scientific and Cultural Organization) on March 4, 2020 suggested distance learning and opened an educational platform that could be used by teachers to reach students from a distance and limited educational disruption [1] . In connection with these developments, the Ministry of Education and Culture or "Kemendikbud" adopted that policy as a guide in dealing with the covid-19 epidemic at the education unit level [2] This is done as an effort to prevent the spread of corona virus spread. Based on this the education unit carries out online learning.

Online learning is learning that utilizes digital technology as medium between teachers and students. In online learning, the learning process can be done anytime, anywhere and in any situation, without being bounded by space and time. In order to remain effective online learning, it needs activeness in learning, because interaction in online learning is to utilize digital technology that is used to access the contents of subject matter and to interact with others. The effectiveness of learning is the teaching behavior of teachers and learning behavior of students. The effectiveness of learning is characterized by the activeness of teachers and students in the learning process, especially the organization and discovery of information. The more active teachers and students are in the teaching and learning process, the more effective learning. Indicators of learning effectiveness are quality, appropriateness, intensive and time, [3]. The use of online discussion group methods in learning is one of the efforts to keep the learning process effective. The discussion method is a way of delivering learning material by exchanging ideas between teachers and students [4]. Along with the development of information technology, the discussion can continue without going faceto-face. Discussions can be held in cyberspace. An online discussion group is a discussion activity that is carried out in an Online network [5]. The online discussion group method is a strategy for delivering learning material by exchanging opinions, generating ideas and testing ideas carried out by teachers and students through digital technology. Online discussion groups can use the WhatsApp (WA) application, Zoom, google classroom, facebook, Instagram, etc. Based on results of the study, the use of the WA in application in physics education assessment subject has a positive effect on student activeness in discussing and studying both of face-to-face learning and online networking [6]. The research result of La Ode in 2020 stated that preferred aplication in online lectures was $91,8 \%$ of studens choosing the WhatsApp group aplication [7]. Based on these results, the authors use the WhatsApp application. 


\section{RESEARCH METHODS}

Researcher used quantitative descriptive as research method. In collecting the data, researcher used a questionnaire with a nominal scale: Yes / no in total of 17 questionnaire items that have met the validity and reliability tests. The subjects of this research are students who took Introduction of management Subject totaled 14 respondents. Data analysis techniques in this research used categorization. To categorize the measurement results, they were grouped into three (3) categories, namely low, medium, high [8].

Table 1. Categorization Criteria

\begin{tabular}{|l|l|}
\hline Low & $\mathrm{X}<\mathrm{M}-1 \mathrm{SD}$ \\
\hline Medium & $\mathrm{M}-1 \mathrm{SD} \leq \mathrm{M}<+1 \mathrm{SD}$ \\
\hline height & $\mathrm{M}+1 \mathrm{SD}$ \\
\hline
\end{tabular}

\section{RESULT AND DISCUSSION}

Based on the results of the analysis with the help of SPSS for Windows 15.0 program, the mean was 14,285 and a standard deviation was 1,938 . The frequency distribution of data can be seen in the following table:

Table 2. Distribution of Learning effectiveness

\begin{tabular}{|ll|l|l|l|l|}
\hline & & Frequency & Percent & $\begin{array}{l}\text { Valid } \\
\text { Percent }\end{array}$ & $\begin{array}{l}\text { Cumulative } \\
\text { Percent }\end{array}$ \\
\hline Valid & Less & 3 & 21.4 & 21.4 & 21.4 \\
& Fair & 8 & 57.1 & 57.1 & 78.6 \\
Effective & 3 & 21.4 & 21.4 & 100.0 \\
Total & 14 & 100.0 & 100.0 & \\
\hline
\end{tabular}

Based on the table 2, it can be stated that the effectiveness of learning which has an effectiveness category is less effective with a frequency of 3 respondents or $21.4 \%$. The category The second category is quite effective with a frequency of 8 respondents or $57.1 \%$. And the last category is Effective with a frequency of 3 respondents or $21.4 \%$. Factors that affect the effectiveness of learning are quality, appropriateness, intensive and time [3]. The online discussion method is one of the quality indicators that affect the effectiveness of learning. It can be seen from the results of categorizing, the use of the online discussion method with the WhatsApp (WA) application that is considered quite effective. In line with the results of the study, Yuberti stated the use of WA in learning has a positive influence on the activeness of learning [5] and research results of La Ode which examined the perceptions of PIAUD students towards online learning, stated that of the 60 respondents where 23 responses answered they understand when they were asked how far their understanding of lecture material [7]. From the factors that influence the effectiveness of learning, namely quality, appropriateness, intensive and time, online discussion method is one of the quality indicators that affect the effectiveness of learning.

\section{CONCLUSION}

Based on the results of the study it can be concluded that the effectiveness of learning using online discussion methods in learning in the category of a pandemic is quite effective.

\section{REFERENCES}

[1] UNESCO, "290 million students out of school due to COVID-19: UNESCO releases first global numbers and mobilizes response," WWW.UNESCO.ORG, Paris, France, 2020.

[2] N. A. Makarim, "Minister of Education and Culture Circular No. 4 of 2020 Concerning Implementation of Education Policies in Emergency Times Spread of CORONA VIRUS DISEASE (COVID-19)," Kemendikbud, Jakarta, 2020.

[3] Slavin, "Educational Psychology," Sixth Edition Boston: Allyn and Bacon, Boston, 2009.

[4] Netti, "Use of Discussion Methods to Improve Learning Outcomes of Social Change Material in Class XII 
Students of SMA Negeri 4 Pekan Baru," vol. 10, no. 2, pp. 155-168, 2015.

[5] Yuberti, " Online Group Discussion in Physics Learning Technology," Scientific Physical Education Al-BiRuN, vol. 2, no. 2, pp. 145-153, 2015.

[6] Khusaini, Agus, and Others, "Optimizing the use of WhatsApp," the JRKPF UAD Physics Education Assessment Lecture, vol. IV, no. 1, 2017.
[7] L. Ode, " Student Perception of Online Lectures in the COVID Pandemic Period 19," Early Childhood Education, vol. III, no. 1, pp. 44-58, 2020.

[8] P. o. t. 2. E. o. P. Scale, Preparation of the 2nd edition of Psychology Scale, Yogyakarta: Student Library, 2012. 